\title{
Students' Perceptions on Educational Environment of Selected Dental Colleges in Bangladesh
}

\author{
Syeda Mahmuda Akhter', AKM Asaduzzaman², Md. Humayun Kabir Talukder ${ }^{3}$, Faisal \\ Solaiman ${ }^{4}$, Arifa Begum ${ }^{5}$
}

\begin{abstract}
This descriptive type of cross-sectional study was conducted with the aim to find out the students' perceptions on educational environment of selected dental colleges in Bangladesh. The study was carried out in ten selected dental colleges ( 4 government \& 6 non-government) of Bangladesh. Total sample size was 1169 of different years of BDS students. Dental colleges were selected purposively \& data was collected from students by adopting convenience sampling technique. Data collection was done with self-administered semi-structured questionnaire with two open questions using Dundee Ready Educational Environment Measurement (DREEM) inventory with some modification. There were five subscales of DREEM for students. Study results revealed that total DREEM score of students were 142 . Mean score of students' perceptions by subscale of DREEM were "students' perception of their learning (34.95); students' perception of their teachers (30.36); students' academic selfperception (24.94); students' perception of educational atmosphere (32.82) and students' social self-perception (18.83). All these values indicated that the students' perception were in the right \& mostly positive direction. Study recommended that significant attention should be paid in few problematic areas specially for "too much teacher centered learning and over emphasized factual learning. Study also recommended to improve the logistic support for students of dental colleges to ensure better educational environment of Bangladesh.
\end{abstract}

Key words: Students' perceptions, dental educational environment, DREEM.

1. Senior Lecturer, Dept. of Periodontology and Oral Pathology, City Dental College, Nikunja-2, Dhaka.

2. Professor\& Head, Department of Community Medicine, Diabetic Association Medical College, Faridpur.I

3. Professor, Curriculum Development \& Evaluation, Centre for Medical Education (CME), Mohakhali, Dhaka.

4. Assistant Professor, Dept. of Prosthodontics, City Dental College, Nikunja-2, Dhaka

5. Lecturer, Dept. of Pharmacology, Tairunnessa Memorial Medical College, Targach, Gazipur.

Address of correspondence: Dr. Syeda Mahmuda Akhter, Senior Lecturer, Dept. of Periodontology and Oral Pathology, City Dental College, Nikunja-2, Dhaka.

\section{Introduction}

The educational environment is everything that happens within the classroom, departments, faculty, and institution both physically and psychologically.

Educational environment is vital in determining the success or failure of any institute. ${ }^{1} \mathrm{~A}$ positive environment leads to Bangladesh Journal of M edical Education 2020; 11(2); Akhter et al., publisher and licensee Association for M edical Education. This is an Open Access article which permits unrestricted non-commercial use, provided the original work is properly cited. achievements, fun, and engagement in learning while a negative one would hinder their accomplishments. So, the educational environment plays a very important role in effective student learning. ${ }^{2}$ An effective educational environment depends on the quality of the leadership, the quality of patient care, the nature of the infrastructure, and the preparation and support of trainers 
so that they are able to deliver their educational role. $^{3}$

The American Medical Association (AMA) defined the learning environment as- "A social system that includes the learner (including the external relationships and other factors affecting the learner), the individuals with whom the learner interacts, the setting(s) and purpose(s) of the interaction, and the formal and informal rules/policies/norms governing the interaction." 4

The medical education environment ideally should foster intellectual activities and progression, while at the same time encouraging friendliness cooperation and support. Measuring such an environment can be extremely complex as it comprises a multitude of settings, for example lecture rooms, laboratories, hospital wards, outpatient clinics and general practice. This multiplicity of educative settings is matched by a range of socializing agents, for example fellow students, lecturers, different departments, clinicians from many specialties, counsellors, tutors, and administrators with the power to influence the nature of the settings. ${ }^{4}$

Students' perception of the environment within which they have a significant impact on their behavior, academic progress and sense of well-being. Educational environment influences how, why and what students learn which is crucial in the success of the curriculum. ${ }^{2,5,6}$

\section{Methodology}

This descriptive type of cross-sectional study was conducted in ten selected dental colleges (4 government \& 6 nongovernment) of Bangladesh. Out of ten dental colleges 7 were within Dhaka and 3 outside Dhaka. The study period was from
July 2017 to June 2018. Sample size was 1169 BDS students of all years. Purposive sampling technique was adopted for selection of dental colleges and convenience sampling technique for collection of data.

The study protocol and instruments were approved by the institutional review board (IRB) of Center for Medical Education (CME), Mohakhali, Dhaka. After pretesting the instrument data collection was done with self-administered semistructured questionnaire with two open questions for the students on the basis of Dundee Ready Educational Environment Measure (DREEM) with some modification considering our country context.

In 1997, Roff et al. published the DREEM scale ("Dundee Ready Education Environment Measure"), which was originally developed by a Delphi panel of nearly 100 educators (specialists in health sciences drawn from 20 different countries).The Dundee Ready Educational Environment Measure (DREEM) is a culturally non-specific, generic and validated instrument. It has high internal consistency which is globally accepted instrument. Five point Likert scale was used to measure the variables. Scores were counted against each point of scale.

There were 50 items for students with some modification of DREEM, among those 10 items were reverse scored for analysis.

All the data were checked, edited to reduce errors and organized manually. The collected data were duly entered, processed and analyzed in SPSS 19 version, according to the specific objectives of the study. Data were presented by tables \& graphs with necessary description for easy understanding and interpretation. 


\section{Result}

Total respondent were 1169, among them 285 were male and 884 were female students.

Table 1 Shows the DREEM subscale and total maximum score, mean score in all respondents. Students' perceptions of learning was $34.95 / 48(73 \%)$ i.e. more positive perception, students' perceptions of teachers was 30.36/48 (63\%) i.e. moving in right direction, students' academic self- perceptions was 24.94/32 (78\%) i.e. feeling more on positive side, students perceptions of atmosphere was 32.82/44 (75\%) i.e. a more positive atmosphere and students social self-perception was 18.83/28 (67\%) i.e. more positive than negative but room for improvement Highest score was found in subscale 3 and lowest in subscale 2 . Total DREEM mean score was $142 / 200$ and when percentage was done it was $71 \%$ and it can be expressedas more positive.

Table 1 Subscale and total DREEM mean score in all students ( $n=1169)$

\begin{tabular}{|l|c|c|l|}
\hline $\begin{array}{l}\text { Sub scales of } \\
\text { DREEM }\end{array}$ & $\begin{array}{c}\text { Maximum score of } \\
\text { Sub scales of } \\
\text { DREEM }\end{array}$ & $\begin{array}{c}\text { Mean score on } \\
\text { students' } \\
\text { perceptions in this } \\
\text { study }\end{array}$ & $\begin{array}{l}\text { Interpretation on } \\
\text { students' } \\
\text { perceptions }\end{array}$ \\
\hline $\begin{array}{l}\text { Students' perception } \\
\text { of learning }\end{array}$ & 48 & $\begin{array}{c}34.95 \\
(73 \%)\end{array}$ & $\begin{array}{l}\text { A more positive } \\
\text { perception }\end{array}$ \\
\hline $\begin{array}{l}\text { Students' perception } \\
\text { of teachers }\end{array}$ & 48 & $\begin{array}{c}30.36 \\
(63 \%)\end{array}$ & $\begin{array}{l}\text { Moving in the right } \\
\text { direction }\end{array}$ \\
\hline $\begin{array}{l}\text { Students' academic } \\
\text { self-perception }\end{array}$ & 32 & $\begin{array}{l}24.94 \\
(78 \%)\end{array}$ & $\begin{array}{l}\text { Feeling more on the } \\
\text { positive side }\end{array}$ \\
\hline $\begin{array}{l}\text { Students' perception } \\
\text { of atmosphere }\end{array}$ & 44 & 32.82 & $\begin{array}{l}\text { A more positive } \\
\text { atmosphere }\end{array}$ \\
\hline $\begin{array}{l}\text { Students' social self- } \\
\text { perception }\end{array}$ & 28 & $\begin{array}{l}(75 \%) \\
(67 \%)\end{array}$ & Not too bad \\
\hline Total DREEM score & 200 & 141.9 & $\begin{array}{l}\text { More positive than } \\
\text { negative but room } \\
\text { for improvement }\end{array}$ \\
\hline
\end{tabular}

Table 2 and 3 presents the individual item mean score in all students. Two items scored less than 2 i.e The teaching is too teacher-centered (1.60) and during teaching more importance is given on theory (lecture class) than clinical/practical work (1.06).Fourteen items scored less than 3.Among them 1 item from subscale1 i.e. The teaching is student-centered (2.06).5 items from subscale 2 i.e. The teachers provide constructive criticism (2.80); The teachers ridicule the students (2.85); The teachers get angry in teaching session (2.78); The teachers are authoritarian (2.38)and the students irritate the teachers (2.72). One item from subscale 3 i.e. I am able to memorize all I need (2.93).Three items from subscale 4 i.e. I get a lot of enjoyment of studying the course (2.98); The assessment system is stressful for me (2.25); The college authority always keep commitment in many aspects of students matter (2.65). 
Table 2 Item mean score in all students $(n=1169)$

\begin{tabular}{|c|c|c|c|}
\hline Subscale & Item no & Item & Mean \\
\hline \multirow[t]{12}{*}{ 1.SPL } & 1 & I am encouraged to participate in the class & 3.51 \\
\hline & 2 & $\begin{array}{l}\text { At the beginning of the teaching session teacher tell what he/she } \\
\text { wants to teach ( learning objectives) }\end{array}$ & 3.43 \\
\hline & 3 & The allocated teaching time is used properly & 3.30 \\
\hline & 4 & The teaching is well focused & 3.31 \\
\hline & 5 & Sometimes the teaching is stimulating & 3.31 \\
\hline & 6 & I feel safe during teaching session (Non-threatening environment) & 3.44 \\
\hline & 7 & The teaching encourages me to be an active learner & 3.38 \\
\hline & 8 & The teaching is student-centered & 2.06 \\
\hline & 9 & The teaching gives opportunity to become lifelong learner & 3.31 \\
\hline & 10 & The teaching helps to develop my competence & 3.26 \\
\hline & 11 & The teaching is too teacher-centered & 1.60 \\
\hline & 12 & $\begin{array}{l}\text { During teaching more importance is given on theory (lecture class) } \\
\text { than clinical/practical work }\end{array}$ & 1.06 \\
\hline \multirow[t]{12}{*}{ 2.SPT } & 13 & The teachers are knowledgeable in their respective subject & 3.51 \\
\hline & 14 & The teachers give clear examples & 3.41 \\
\hline & 15 & The teachers are well prepared for their teaching session & 3.36 \\
\hline & 16 & The teachers have good communications skills & 3.25 \\
\hline & 17 & The teachers provide good feedback to the students & 3.22 \\
\hline & 18 & The teachers provide constructive criticism & 2.80 \\
\hline & 19 & The teachers ridicule the students & 2.85 \\
\hline & 20 & The teachers get angry in teaching session & 2.78 \\
\hline & 21 & The teachers are authoritarian & 2.38 \\
\hline & 22 & The teachers have patience in teaching session & 3.13 \\
\hline & 23 & The teachers use sufficient quality instructional materials & 3.06 \\
\hline & 24 & The students irritate the teachers & 2.72 \\
\hline \multirow[t]{8}{*}{ 3. SASP } & 25 & I am confident about passing this year & 3.16 \\
\hline & 26 & I feel I am being well prepared for my profession & 3.17 \\
\hline & 27 & I am able to memorize all I need & 2.93 \\
\hline & 28 & Last year performance will help me for preparation of this year & 3.05 \\
\hline & 29 & My problem-solving skills are being well developed here & 3.12 \\
\hline & 30 & $\begin{array}{l}\text { Much of what I am learning seems relevant to my future career } \\
\text { (dentistry) }\end{array}$ & 3.19 \\
\hline & 31 & I am developing a lot about empathy in my profession & 3.22 \\
\hline & 32 & $\begin{array}{l}\text { Previously adopted learning strategies are still helpful for my } \\
\text { learning }\end{array}$ & 3.08 \\
\hline \multirow[t]{11}{*}{ 4. SPA } & 33 & The atmosphere promotes mutual respect during teaching session & 3.22 \\
\hline & 34 & This college is well time- tabled & 3.12 \\
\hline & 35 & I am able to ask the questions I want & 3.19 \\
\hline & 36 & I feel comfortable in class & 3.16 \\
\hline & 37 & I have opportunity to develop interpersonal skill & 3.01 \\
\hline & 38 & The atmosphere is relaxed during class & 3.01 \\
\hline & 39 & I get a lot of enjoyment of studying the course & 2.98 \\
\hline & 40 & The atmosphere motivates me as a learner & 3.08 \\
\hline & 41 & I am able to concentrate well in my learning & 3.02 \\
\hline & 42 & The assessment system is stressful for me & 2.25 \\
\hline & 43 & $\begin{array}{l}\text { The college authority always keep commitment in many aspects of } \\
\text { students matter }\end{array}$ & 2.65 \\
\hline
\end{tabular}

SPL=students perception of learning, SPT= Student's Perceptions of Teachers, SASP= Student's Academic Self-Perceptions, SPA= Student's Perceptions of Atmosphere.

\section{NB: Negative statements are in italic form \& mean was calculated with reverse score}

Bangladesh Journal of M edical Education 2020; 11(2); Akhter et al., publisher and licensee Association for M edical Education. This is an Open Access article which permits unrestricted non-commercial use, provided the original work is properly cited. 
Table 3 Item mean score in all students $(n=1169)$

\begin{tabular}{|llll|}
\hline Subscale & Item no & \multicolumn{1}{c|}{ Item } & Mean \\
\hline 5. SSSP & 44 & I have good friends in this college & 3.43 \\
& 45 & My accommodation is pleasant in the class & 3.12 \\
& 46 & Sometimes I am bored on this course & 2.05 \\
& 47 & I am too tired to enjoy this course & 2.39 \\
& 48 & There is a good support system for students who get stressed & 2.66 \\
& 49 & My social life is good & 3.03 \\
& 50 & Sometimes I feel lonely & 2.13 \\
\hline
\end{tabular}

\section{SSSP $=$ Student's Social Self Perceptions.} NB: Negative statements are in italic form \& mean was calculated with reverse score and 4 items from subscale 5 i.e. Sometimes I am bored on this course (2.05); I am too tired to enjoy this course (2.39); There is a good support system for students who get stressed (2.66) and sometimes I feel lonely (2.13). Among 50 items two items scored more than 3.5 i.e. I am encouraged to participate in the class (3.51) and the teachers are knowledgeable in their respective subject (3.51). Others 32 items scored between 3-3.5.

\section{Discussion:}

In this study we reported the results of educational environment from the undergraduate Dental Colleges in Bangladesh. The DREEM questionnaire has provided an overview of students' perception throughout the dental colleges and allowed areas of concern to be highlighted for remedial actions.

The overall mean DREEM score in the current study was $142 / 200(71 \%)$ points for the students $(n=1169)$. Study findings were within the accepted range of 101-150 points that is an indicative of a "more positive than negative" perception. In this study total score $(142 ; 71 \%)$ was consistent with the studies in British and Swedish medical schools that have obtained scores between 141 and $150 . .^{8,9}$
The DREEM can be used to pinpoint more specific strengths and weaknesses within the educational climate. To do this we need to look at the responses to individual item. Items that have a mean score of 3.5 or more are real positive points. Any item with a mean of 2 or less should be examined more closely as they indicate problem areas. Items with a mean of 2-3 are aspects of the climate that could be enhanced.

There were two negative statements made by students regarding SPL. In several studies ${ }^{10}$ including this study on EC using the DREEM scale, students complained about "too much teacher-centered teaching (scored 1.60) and over emphasizes factual learning (1.06)." Factual learning might be due to the pattern of formative and summative assessments encountered by the students. So we must put more emphasis on improving these weaknesses and on ensuring future development of the total dental educational environment of Bangladesh. Items scored less than 3 like 'The teachers provide constructive criticism', 'the teachers are authoritarian', 'the students irritate the teachers' Many study findings were similar with this study. ${ }^{11-16}$ These perceptions need further investigation to identify the means of improving these issues. Consideration may be given to creation of cooperative and congenial teacher-students' relationship in near future to develop. 


\section{Conclusion}

In the present study after reviewing the findings it can be concluded that the students' perceptions on dental educational environment were more positive. Overall score of DREEM inventory indicated more positive perception than negative but there were room for improvement. Mean score of students perceptions on subscales of DREEM were in the right direction.

\section{References:}

1. Lizzio A, Wilson K, Simons R2002. University students' perceptions of the learning environment and academic outcomes: Implications for theory and practice. Study Higher Educ; 27: 2752.

2. Genn J.M. 2001b. AMEE Medical Education Guide No. 23 (Part 2): curriculum, environment, climate, quality and change in medical education - a unifying perspective. Med Teach; 23 (5): 445-54.

3. General Medical Council. May2013.Approving Educational

Environment

4. Genn JM 2001a. AMEE Medical Education Guide No.23 (Part 1): Curriculum, environment, climate, quality and change in medical education-a unifying perspective. Med Teach; 23: 337-44

5. Pimparyon $P$, Roff $S$, McAleer $S$, Poonchai B, Pemba S.2000.

Educational environment, student approaches to learning and academic achievement in a Thai nursing school. Medical Teacher; 22(4): 359-65.
6. Audin K, Davy J, Barkham M University Quality of Life and Learning (UNIQoLL) 2003: an approach to student wellbeing, satisfaction and institutional change. Journal of Further \& Higher Education; 27(4): 365-82.

7. Roff S, McAleer S, Harden RM, AlQahtani M, Ahmed AU, Deza H, Groenen G, Primparyon P. 1997. Development and validation of the Dundee Ready Education Environment Measure (DREEM). Med Teacher; 19(4): 295-99.

8. Edgren G, Haffling AC, Jakobsson U, McAleer S, Danielsoen N 2010.

Comparing the educational environment (as measured by DREEM) at two different stages of curriculum reform. Med Teach; 32: e233-e238.

9. McKendree J 2009. Can we create an equivalent educational experience on a two campus medical school? Med Teach; 31: e202-e205.

10. Khattak O, Adeel M. 2016. Perceptions of Dental Students Studying at Ras Al Khaimah College of Dental Sciences to Their Educational Environment Using the Dundee Ready Educational Environment Measure -DREEM. JIIMC;11(4):

11. Thomas BS, Abraham RR, Alexander M, Ramnarayan K 2009. Students' perceptions regarding educational environment in an Indian dental school. Med Teach; 31: e185-e186.

12. Tomás I, Palés J 2012. Spanish dental students' perception of the "Educational Climate".Medical Teacher.

13. Kohli V, Dhaliwal U 2013. Medical students' perception of the educational environment in a medical college in India: a cross-sectional study using the

Bangladesh Journal of M edical Education 2020; 11(2); Akhter et al., publisher and licensee Association for M edical Education. This is an Open Access article which permits unrestricted non-commercial use, provided the original work is properly cited. 


\section{Original Article}

Dundee ready education environment questionnaire. J Educ Health Prof; 10:

14. Jawaid M, Raheel S, Ahmed F, Aijaz H. 2013. Students' perception of educational environment at Public Sector Medical University of Pakistan. $J$ Res Med Sci; 18(5): 417-421.15 Zawawi AH, Elzubbeir M 2012. Using DREEM to compare graduating students' perceptions of learning environments at medical schools adopting contrasting educational strategies. Med Teach; 34: S25-S31.
15. Ahmad MS, Ahmed B, Hani T. Fadel, Mohammad S, Mahrous. 2015. Comparing dental students' perceptions of their educational environment in Northwestern Saudi Arabia. Saudi Med $J ; 36$ (4): 477-483.

Bangladesh Journal of M edical Education 2020; 11(2); Akhter et al., publisher and licensee Association for M edical Education. This is an Open Access article which permits unrestricted non-commercial use, provided the original work is properly cited. 